\title{
ELECTROMOBILITY DEVELOPMENT IN SELECTED EUROPEAN COUNTRIES IN THE LIGHT OF AVAILABLE TAX CONCESSIONS
}

\author{
JAROSŁAW JAWORSKI \\ University of Szczecin, Faculty of Management and Economics of Services, POLAND \\ e-mail: jaroslaw.jaworski@wzieu.pl
}

RECEIVED
ACCEPTED
JEL
CLASSIFICATION

KEYWORDS economic geography, tax concessions, Electric Vechicles market, EV policy

ABSTRACT The legal regulations concerning the development of the alternative fuel vehicles market introduced by individual European countries are designed to minimize the impact of transport on the environment and to increase the independence from oil. Tax concessions are an important factor of electromobility development in Europe. The aim of the publication is to analyze the differentiation of electromobility development level in selected European countries in the context of tax concessions. The applied research methods are: critical analysis of the literature on the subject (theoretical approach to issues related to low-emission economy and electromobility), secondary analysis of documents (desk research) involving the interpretation of sales data and tax concessions in selected countries and the method of logical reasoning contributing to the presentation of applications and implementation of the purpose of publication. The conclusions included in the final part of the article concern the identification of the interaction planes of tax concessions impact on the EV's (Electric Vechicles) market development.

\section{Introduction}

The development of modern technologies in the field of low-emission transport is highly related to the global environmental pollution reduction plans. The increase of the awareness of modern societies about the importance of ecology stimulates both legislative changes as well as shopping preferences. One of the most noticeable manifestations of this change is the increase of EV's sales. Until now, the leading models among EV's 
were the models that used a hybrid system, ie one that combines two independent engines: traditional and electric. Global trends indicate successive but slow displacement of purely internal combustion vehicles from the market (Kurtyka, 2018, p. 19). These changes are dictated not only by the mentioned increase in the consumers ecological awareness but also by the first declarations of the authorities of countries such as Norway, Germany, Great Britain, France or the Netherlands, which set deadlines for the final withdrawal of diesel and petrol powered cars from the market (Dugdale, 2018).

\section{The essence of electromobility and types of the electric vechicles}

Electromobility is a concept that focus at all the problems related to wheeled transport (technical, infrastructural, legislative and market) carried out by electric vechicles supplied with energy stored in batteries (Mataczyński, 2018, p. 11). The social effects, increasing social awareness and ensuring demand for transport services using electricity through the development of zero- and low-emission vehicle fleets and public transport are not without significance for the development of electromobility. These activities are aimed at reducing emissions, and consequently improving the quality of air and the health of people (Pilecki, 2019). Due to the type of drive used, we distinguish the following basic classes of passenger electric vehicles:

1. Battery Electric Vehicle (BEV) - a battery-powered electric vehicle equipped exclusively with an electric motor and a battery, without the support of a traditional internal combustion engine. The vehicle is powered by connecting to an external source of electricity through a dedicated charger. Like other electric vehicles, $B E V$ can recharge its batteries in a process known as regenerative braking, which uses the electric motor of the vehicle to slow down the vehicle, and recover some of the energy usually converted from the heat generated by the brakes (Carley, 2014, p. 3).

2. Plug-in Hybrid Electric Vehicle (PHEV) - hybrid vehicles. They are powered by both traditional fuel and electricity. PHEV hybrids can charge batteries through regenerative braking as well as connection to an external electrical charging socket. (Https://www.ergon.com.au). Cars of this type at distances up to $50 \mathrm{~km}$ mainly use an electric engine, whereas the internal combustion engine is activated on longer routes.

3. Hybrid Electric Vehicles (HEVs) - colloquially called the "full hybrid" it uses the power of the internal combustion engine and electric motor. From a PHEV vehicle it is distinguished by the lack of the possibility of recharging batteries from an external source of electricity.

4. Fuel Cell Vehicles (FCV) - uses fuel cells, powered by hydrogen, which produce electricity for the electric motor and batteries cooperating with it as a result of a chemical reaction.

Each of the above-mentioned types of vehicles can be considered ecological in relation to classic internal combustion drives. However, when comparing individual vehicle classes (EVs), they can be divided into those that emit a limited amount of carbon dioxide and other toxic substances (PHEV and HEV) and so-called "Zero-emission" vehicles (BEV and FCV). The concept model representing the BEV zero-emission vehicle class is shown in the Figure 1. 


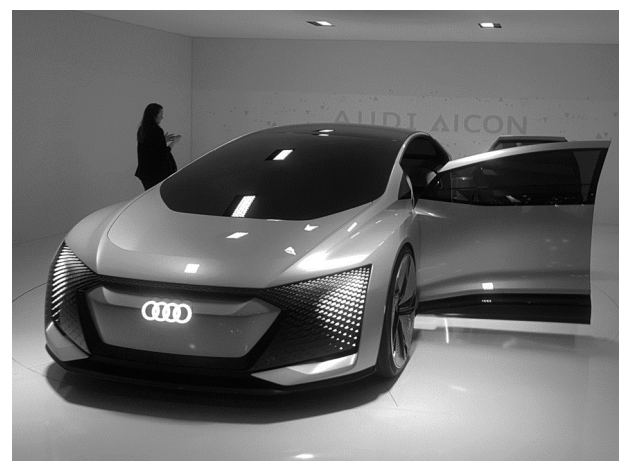

Figure 1. Audi Aicon at Motor Show Poznań 2018

Source: author.

Hybrids, compared to zero-emission cars (currently offered in dealerships) have the advantage of real range. According to the BEV car test carried out by the automotive magazine Auto Świat, the vehicle with the largest real range turned out to be the Tesla S model, which covered $422 \mathrm{~km}$ on one charge (Mroczek, 2018). Vehicles of the FCV type, such as the Toyota Mirai, have similar range as BEV cars, but they also have one significant advantage, namely the time of their charging / refueling is much shorter.

\section{Sale of cars with electric drives in selected European countries}

There is no doubt that the automotive market is currently dynamically changing. Everything indicates that we are entering the era of electric vehicles. The number of alternative vehicles sold is growing each year. A list of sales of such vehicles in selected European countries is provided in the Table1.

Table 1. Electric car stock (BEV and PHEV) in selected European countries, 2010-2017 (in thousands)

\begin{tabular}{lccccccccr}
\hline \multicolumn{1}{r}{ Country } & 2010 & 2011 & 2012 & 2013 & 2014 & 2015 & 2016 & 2017 \\
\hline Norway & 0.79 & 2.63 & 7.15 & 15.67 & 35.44 & 69.17 & 114.05 & 176.31 \\
France & 0.30 & 3.03 & 9.29 & 18.91 & 31.54 & 54.49 & 84.00 & 118.77 \\
Germany & 0.25 & 1.89 & 5.26 & 12.19 & 24.93 & 48.12 & 72.73 & 109.56 \\
Netherlands & 0.27 & 1.14 & 6.26 & 28.67 & 43.76 & 87.53 & 112.01 & 119.33 \\
Sweden & - & 0.18 & 1.11 & 2.66 & 7.32 & 15.91 & 29.33 & 49.67 \\
Finland & - & 0.06 & 0.24 & 0.47 & 0.93 & 1.59 & 3.29 & 6.34 \\
United Kingdom & 1.68 & 2.89 & 5.59 & 9.34 & 24.08 & 48.51 & 86.42 & 133.67 \\
\hline
\end{tabular}

Source: own elaboration based on data from the International Energy Agency... (2018).

Based on the data in the table above, the following observations can be deduced:

1. The electric car market in Europe was born around 2010.

2. Norway is the leader in terms of the largest number of cars sold.

3. The largest increase in sales of cars from year to year was recorded in Norway. 
4. The smallest increase in sales of cars from year to year was recorded in Finland.

5. Each year, there is a general increase in sales in every country.

6 . The sale of electric cars is forecasted to grow for the coming years.

Certainly, it is also worth paying attention to several aspects that can affect the sales indicators in a real way. These include, for example, the level of development of the available infrastructure (charging stations) for EV's, the level of affluence of the society or available tax concessions (presented in the next paragraph). An important feature is also the use of EV's and hybrids in transport companies. The use of cost concessions (more precisely in the next paragraph) makes it easier to build an electric fleet as a tool for business owners that develop in accordance with the principle of corporate social responsibility, for example sustainable development with maintaining environmental protection. Transport companies emit significant amounts of exhaust gases into the atmosphere, which is why it is an important element of their activity to reduce bad emissions. This is also related to the low-emission economy, which is characterized by economic growth while reducing greenhouse gas emissions, mainly due to limiting the use of fossil fuels (Pilecki, 2018, p. 212). Currently, from the car fleet owner point of view, electric vehicles are not profitable, among others due to the limited range of use. In the future, technological progress is expected to improve this indicator. However, it is invariably extremely interesting, constantly monitored by transport companies, direction of development of the automotive market.

\section{Available tax concessions related to the purchase and use of alternative-powered vehicles in selected European countries}

Alternative cars are now promoted as an ecological alternative to diesel and petrol. And although we see them more and more on the road, for many drivers the price of such a vehicle is still too high. In order to develop a stable and developmental market for electric vehicles, many benefits associated with the purchase and use of these vehicles are presented. These are both law regulations (in the form of laws and norms) and economic premises (Table 2).

Table 2. Tax incentives for electric vechicles in the selected European countries

\begin{tabular}{cl}
\hline Country & \multicolumn{1}{c}{ Incentives } \\
\hline 1 & \\
\hline & - no purchase/import taxes, \\
& - exemption from $25 \%$ VAT on purchase, \\
& - no annual road tax, \\
& - charges were introduced on ferries with upper limit of maximum $50 \%$ of full price, \\
& - charges on toll roads were introduced with upper limit of maximum $50 \%$ of full price, \\
Norway & - parking fee for EVs was introduced locally with an upper limit of maximum $50 \%$ of full price, \\
& - access to bus lanes, \\
& $-50 \%$ reduced company car tax, \\
& - company car tax reduction was lowered to $40 \%$, \\
& - fiscal compensation for scrapping of fossil vans when converting to a zero emission van, \\
& - allowing holders of driver licence class B to drive electric vans class C1 (light lorrries) up to $2450 \mathrm{~kg}$ \\
\hline
\end{tabular}


1

- each region have the option to provide an exemption from the registration tax (either total or $50 \%$ ) for alternative fuel vehicles (ie electric, hybrids, CNG, LPG, and E85),

- electric vehicles and vehicles emitting less than $60 \mathrm{~g} \mathrm{CO}_{2} / \mathrm{km}$ are not subject to the tax on company cars,

France $\quad-$ electric and hybrid electric vehicles emitting $20 \mathrm{~g} / \mathrm{km}$ or less of CO 2 benefit from a premium of $€ 6,000$ under a bonus-malus scheme,

- an incentive scheme grants an extra $€ 4,000$ for switching an eleven year or more diesel vehicle for a new BEV (or € 2,500 in case it's a PHEV)

- electric vehicles are exempt from the annual circulation tax for a period of ten years from the date of their first registration,

Germany - from July 2016, the government granted an environmental bonus of $€ 4,000$ for pure electric and fuel-cell vehicles and $€ 3,000$ for plug-in hybrid and range-extended electric vehicles

- zero emission cars are exempt from paying registration tax,

Netherlands - passenger cars with zero $\mathrm{CO}_{2}$ emissions are exempt from motor vehicle tax up to and including 2020 ,

- zero emission cars pay the lowest percentage (4\%) of the income tax on the private use of a company car

- 'climate bonus' (Klimatbonus) is available for the purchase of new vehicles with $\mathrm{CO}_{2}$ emissions of maximum $60 \mathrm{~g} / \mathrm{km}$. It ranges from

SEK 60,000 for electric vehicles (BEV) with zero emission to plug-in hybrids (PHEV) with emission of $60 \mathrm{~g} / \mathrm{km}$,
- electric cars and plug-in hybrids are exempted from paying annual circulation tax for five years $40 \%$ reduction is applied on company car taxation for electric cars and plug-in hybrids

Finland - pure electric vehicles always pay the minimum level of the $\mathrm{CO}_{2}$ based registration tax

United - from April 2018 until March 2021, cars that emit less than $50 \mathrm{~g} / \mathrm{km}$ qualify for $100 \%$ first year writing down allowances (FYAs),

Kingdom - zero emission vehicles attract a zero rate of vehicle excise duty (VED),

Kingdom - ultra-low emissions and electric vehicles pay reduced company car tax rates

Source: own elaboration based on data from ACEA's Overview on tax incentives for electric vechicles in the EU and Norwegian EV policy on Norsk elbil forening.

The presented solutions are designed to encourage a potential client (private and enterprise) to buy an EV car. Tax concessions introduced by local governments place electric cars in a better position than vehicles with a standard internal combustion engine, both when it comes to purchasing for private persons and companies interested in building a fleet. Norway is a definite leader when it comes to a number of advantages and privileges. In addition, the legal regulations introduce minimum fees depending on the emission, and even exempt the tax on registration of the vehicle (Norway, France or the Netherlands). Entrepreneurs are also expected to be attracted by a low income tax on incomes achieved using electric cars (the Netherlands or United Kingdom). Financial subsidies are also used when replacing an old car with a diesel engine for an electric or hybrid vehicle (France). There are also a number of privileges generally used in all of the countries listed above. Electric vehicles as well as hybrids can move with lanes intended only for public transport (bus lanes). In addition, Clean Air Transport Zones are located in many European capitals for the improvement of air quality. Another bonus is the fact that $\mathrm{EV}$ cars can move freely in these areas without additional charges, as opposed to cars with increased emissions for which the proportional charges apply. Electric car is in many respects more attractive than a standard combustion vehicle. Both in terms of the comfort, desgin, driving or even failures, since the owner of such vehicle does not have to worry about troublesome oil changes or filters. One of the most important arguments for buying an electric car is also the cost of use. In the era of constantly rising costs of fuel prices, the costs of electricity needed to charge the vehicle are relatively low and can be a serious alternative. Combining benefits related to the purchase and operation of EV, this is definitely an interesting alternative for existing vehicles with a combustion drive. 


\section{Conclusions}

The EV's market is developing dynamically. Despite many legal and economic conditions regarding the purchase of vehicles, every year there is a significant increase in sales, often several hundred percent. The unquestionable leaders in the development of the EV's market in Europe are those in which on the one hand, the final dates of withdrawal from the sale of cars were declared on the internal combustion engines (Great Britain, Germany, the Netherlands, Norway and France), and on the other hand, a system of incentives and tax incentives is being built to encourage potential private, institutional and business buyers to purchase. The dynamic development of fast charging and energy storage technology for the automotive industry means that new car models entering the market are characterized by an increasing range and shorter charging time. However, it should be noted that there are differences in the dynamics of EV sales growth between selected countries. Undoubtedly, it has a connection, not only with the application of restrictions on the sales of cars with traditional propulsion, but above all with the use of various tax concessions.

\section{Referencess}

Carley, D. (2014). The Beginners Guide to Electric Vehicles. Retrieved from: https://pluginbc.ca/wp/wp-content/uploads/2017/02/ EVBeginnersGuide_V7.pdf.

Dugdale, M. (2018). European countries banning fossil fuel cars and switching to electric. Retrieved from: https://www.roadtraffictechnology.com/features/european-countries-banning-fossil-fuel-cars.

International Energy Agency Global EV Outlook 2018 (2018). Retrieved from: http://centrodeinnovacion.uc.cl/assets/uploads/2018/12/ global_ev_outlook_2018.pdf.

Kurtyka, M. (2018). Rozwój elektromobilności w Polsce w kontekście wyzwań współczesnej polityki gospodarczej. In: W. Drożdż (ed.), Elektromobilność w rozwoju miast. Warszawa: Wydawnictwo Naukowe PWN.

Mataczyński, M. (2018). Elektromobilność jako przyszłość transport zrównoważonego. In: W. Drożdż (ed.), Elektromobilność w rozwoju miast. Warszawa: Wydawnictwo Naukowe PWN.

Mroczek, P. (2018). Sprawdzamy realny zasięg samochodów elektrycznych. Retrieved from: www.auto-swiat.pl/testy/sprawdzamyrealny-zasieg-samochodow-elektrycznych/mfxebd.

Norway is leading the way for a transition to zero emission in transport (2018). Retrieved from: https://elbil.no/english/norwegian-ev-policy.

Overview on tax incentives for electric vechicles in the EU (2019). Retrieved from: https://www.acea.be/uploads/publications/ EV_incentives_overview_2018_v2.pdf.

Pilecki, B. (2018). Regional operational programs $2014-2020$ as a financial instrument supporting low-carbon economy in Poland on the example of the West Pomeranian Voivodeship. European Journal of Service Management, 3 (27), 211-216.

Pilecki, B. (2019). The Low-Carbon Transport Fund as a source of financing the electromobility development in Poland. Ekonomiczne Problemy Usług (in press).

Types of electric vechicles (2019). Retrieved from: https://www.ergon.com.au/network/smarter-energy/electric-vehicles/typesof-electric-vehicles.

Cite this article aS: Jaworski, J. (2018). Electromobility development in selected European countries in the light of available tax concessions. European Journal of Service Management, 4 (28/2), 187-192. DOI: 10.18276/ejsm.2018.28/2-23. 